\title{
Prostaglandins and its analogues: An approach for treatment of anoestrus and to enhance breeding efficiency
}

\author{
G B Dudhatra, S K Mody, H B Patel, C M Modi, A B Chukewar, Avinash Kumar, M M Awale \\ Department of Pharmacology and Toxicology \\ College of Veterinary Science and Animal Husbandry \\ Sardar Krushinagar Dantiwada Agricultural University, Sardarkrushingar - 385 506, Gujarat, India \\ Corresponding Author: G B Dudhatra, email: drgvets@gmail.com \\ Received: 10-10-2011, Accepted: 24-11-2011, Published Online: 10-03-2012 \\ doi: 10.5455/vetworld.2012.378-384
}

\begin{abstract}
Cloprostenol is a synthetic prostaglandin $\mathrm{F}_{2 a}$ analogue. It is a FP (Prostaglandin F) receptor agonist, which shows powerful luteolytic effects. It also stimulates the contraction of uterine and bronchial smooth muscle and produces vasoconstriction in some vessels. Anoestrous may be due to some conditions like abnormal pregnancy, early pregnancy, pyometra, endometritis, retention of placenta, maceration and mummification. So, get rid of this conditions cloprostenol is widely used. It has been now in vogue to administer PGF $_{2 \alpha}$ or its analogue in early postpartum cows and buffaloes in order to hasten early resumption of cyclic ovarian activity and thereby to increase the reproductive efficiency. To improve reproductive efficiency, it is necessary to inseminate cows early in the breeding season so that, thereby achieving a more compact calving season. Breeding efficiency is increased by means of synchronization of estrus, conception rate and pregnancy rate. Estrus synchronization can be achieved by lysis of corpus luteum by administration of prostaglandin $\left(\mathrm{PGF}_{2 \alpha}\right)$ or its synthetic analogue on 5-17 days of the estrus cycle. The cows will return to estrus within 3-5 days. The effective therapeutic doses for cloprostenol are $500 \mu \mathrm{g}$ in cattle and $175 \mu \mathrm{g}$ in pigs. However, for R-cloprostenol, the recommended doses are: $150 \mu \mathrm{g}$ in cattle and $75 \mu \mathrm{g}$ in pigs. In both cases, it is administered by the intramuscular route.
\end{abstract}

Keywords: Anoestrus, Breeding efficiency, Cloprostenol, Reproduction.

To cite this article: Dudhatra GB, Mody SK, Patel HB, Modi CM, Chukewar AB, Kumar A, Awale MM (2012). Prostaglandins and its Analogues: An approach for Treatment of Anoestrus and to enhance Breeding Efficiency, Vet. World 5(6): 378-384, doi: 10.5455/vetworld.2012.378-384

\section{Introduction}

The successful economics of a dairy farm production lies in ensuing proper and optimal reproductive rhythm of each individual cow and buffaloes in the herd, within the normal physiological range. Any deviation in the breeding rhythm results in a progressive economic loss due to widening of dry period, reduced calving and lactation during the life span of animal. Infertile animal means a direct loss in milk production, whereas reduced calf crops hamper the selection efficiency in long-term dairy herd improvement. Thus, fertility and breeding efficiency of dairy animals plays a pivotal role in dairy economics. The goals for the reproductive management are to increase the milk productivity and reproductive capabilities of cows and young stocks.

Economy of dairy farming largely depends on pregnancy rate. The twelve-month calving interval is advantageous for maximal milk yield per cow per year [1]. It is accepted that bovine genital infections, either specific or non-specific in nature, account for large number of pregnancy failure in cows [2]. Generally, non-specific infection of the genitalia is considered to be the main cause of repeated conception failure [3]. Bacterial infection is the most important among the various causes of the sub-fertility [4]. Such a condition may cause cervicitis or endometritis of various degrees, which in turn may lead to embryonic death and repeat breeding problems [5]. These infections affect fertility by altering the uterine environment, resulting in impairment of sperm transport, sperm death and hostile environment to the subsequent development and maintenance of the conceptus leading to early embryonic death. Early embryonic death is a major factor in reproduction failure [6].

Immediately after calving, the uterus of over 
$90 \%$ of all dairy cows becomes infected with bacteria [7]. Delayed uterine clearance which leads to retention of placenta and subsequent development of anoestrus condition, reduced breeding efficiency, endometritis and pyometra are major problems contributing to subfertility and infertility in farm animals. The clinical syndrome of delayed uterine clearance is characterized by an accumulation and retention of fluid or pus within the uterine lumen, suppression of the estrous cycle and in severe condition animals may die. There is often a negative effect on fertility, milk production and overall health of the farm animals.

Prostaglandins are tissue hormones and are also known as 'autocids'. There are four prostaglandin groups, which are A, B, E and F according to their structure and function. Out of these, $\mathrm{PGF}_{2 \alpha}$ and Prostaglandin $\mathrm{E}$ are the most important ones which have direct effect on reproductive organs and fertility. Prostaglandins are synthesized from arachidonic acid. Fluprostenol, Cloprostenol, Dinoprost, Tiaprost and Luprostiol are synthetic $\mathrm{PGF}_{2 \alpha}$ analogues [8]. Prostaglandins have ecbolic properties and used to expel intraluminal uterine contents as well as cause lysis of the corpus luteum [9]. $\mathrm{PGF}_{2 \alpha}$ and its analogues are applied in different ways including intramuscular, intrauterine, intravenous, intraovarian, intracervical and intravulvo-submucosal routes [10]. The cloprostenol (a synthetic prostaglandin analogue) has been used to treat the condition like anoestrus, retained placenta, endometritis and pyometra. It has been also used to improve breeding efficiency. This essay will illustrate the role of cloprostenol in anoestrus and to improve breeding efficiency.

\section{Structure and Properties}

Prostaglandin is a group of components derived from unsaturated C-20 fatty acids, primarily arachidonic acid. Most prostaglandins have double bonds at 5-6 and 13-14 carbons. Double bonds at carbons 13-14 and an-OH group at C-15 are essential for biological activity [11]. Cloprostenol is a synthetic prostaglandin $\mathrm{F}_{2 \alpha}$ analogue. It is a FP (Prostaglandin F) receptor agonist [12], which shows powerful luteolytic effects. Prostaglandin $\mathrm{PGF}_{2 \alpha}$ analogue also stimulates the contraction of uterine and bronchial smooth muscle and produces vasoconstriction in some vessels.

Cloprostenol sodium salt is a white or off-white hygroscopic powder; freely soluble in water and alcohol. Cloprostenol sodium salt is soluble in organic solvents such as ethanol, DMSO (Dimethyl Sulfoxide) and dimethyl formamide. The solubility of cloprostenol sodium salt in these solvents is 50, 60, and $130 \mathrm{mg} / \mathrm{ml}$, respectively.
The molecular formula and molecular weight of cloprostenol sodium are $\mathrm{C}_{22} \mathrm{H}_{28} \mathrm{ClNaO}_{6}$ and 446.90 respectively. In IUPAC Cloprostenol is (Z)-7[(1R,3R,5S)-2-[(E,3R)-4-(3-chlorophenoxy)-3hydroxybut-1-enyl]-3,5-dihydroxycyclopentyl]-hept5-enoic acid.

Cloprostenol is a synthetic racemic analogue of prostaglandin $\mathrm{F}_{2 \alpha}$. Normally a racemic mixture of both the enantiomers R-cloprostenol and S-cloprostenol is obtained by the chemical synthesis. By means of a specially designed synthetic path and a chromatographic method, the enantiomers can be separated and pure R-cloprostenol can be isolated. Both cloprostenol and the pure R-cloprostenol are used in veterinary medicinal products.

In body it get metabolized to 9,11- dihydroxy 15-cetoprost-5 -enoic acid and 9, 11, 15trihydroxyprost-5-enoic acid which rapidly get excreted from the blood through urine. Its half life is 13 hours.

\section{Mechanism of Action}

Prostaglandins are assumed to be important local regulators of luteal function in almost all mammals. Production of both luteotrophic and luteolytic prostaglandins and expression of specific prostaglandin binding sites have been verified in the corpora lutea of non-primate [13] and primate species [14]. PGF $_{2 \alpha}$ has been found to reduce the concentration of progesterone released by luteal tissue in vivo [15] and in vitro [16] via stimulation of Protein Kinase-C.

Cloprostenol acts as a potent luteolytic agent, which causes functional and morphological regression of the corpus luteum in cattle and horses [17]. It also causes the myometrium contraction [18] and partial cervical relaxation. Cloprostenol exhibit luteolytic activity during the 5 to 15 day of estrus cycle. Progesterone, by its inhibitory effect, inhibits the myometrial contraction and the corpus luteum is the main source of progesterone in estrus animals. Luteolytic effect of $\mathrm{PGF}_{2 \alpha}$ occurs via luteal membrane $\mathrm{PGF}_{2 \alpha}$ receptor [19]. Administration of $\mathrm{PGF}_{2 \alpha}$ and its agonist (cloprostenol) is the treatment of choice for cases of endometritis and pyometra in which corpus luteum is present. Only $1 \mathrm{mg}$ of $\mathrm{PGF}_{2 \alpha}$ given intramuscularly is required to induce luteolysis in the mare, but $25 \mathrm{mg}$ intramuscularly is required in cows [11].

Apart from luteolytic action cloprostenol may also be used for the induction of parturition in pregnant cows, sows and mares. It was demonstrated that only the R-enantiomer of cloprostenol exhibits the 
luteolytic activity. The biological activity of its major metabolite is at most one hundredth of that of cloprostenol.

\section{Role in Treatment of Anoestrus}

Systematic reproductive management programs are increasingly being applied on modern dairy farms. These programs permit control of time to first Artificial Insemination and reduction or elimination of detection of estrus. Reduction in pregnancy risk is exaggerated among cows diagnosed as anovulatory at the start of an ovulation-synchronization protocol. Failure to display estrus before the end of the voluntary waiting period was predictive of future reproductive failure. Cows diagnosed as anestrous include cows that fail to ovulate and those that ovulate in the absence of behavioral estrus. Anoestrous may also be due to some conditions like abnormal pregnancy, early pregnancy, pyometra, endometritis, retention of placenta, maceration and mummification. So, for the get rid of this conditions cloprostenol (synthetic analogue of $\left.\mathrm{PGF}_{2 \alpha}\right)$ is widely used.

In recent years, routine preventive procedures have been developed to optimize and maintain a high degree of breeding efficiency in dairy herds. All the buffaloes and cows under such programs are usually examined routinely at approximately 25 - 30 days after calving to determine the degree of ovarian activity and uterine involution and changes in the reproductive tract that has as early as occurred since parturition. Frequent examinations may be carried out during the course of postpartum phase on buffaloes and cows with any abnormalities in the genital discharge, estrus rhythm and in those that suffered from anoestrus, suboestrus or repeat breeding to arrive at an accurate early diagnosis and implement proper therapy. It has been now in vogue to administer $\mathrm{PGF}_{2 \alpha}$ or its analogue in early postpartum cows and buffaloes in order to hasten early resumption of cyclic ovarian activity and thereby to increase the reproductive efficiency [20].

Treatment with $\mathrm{PGF}_{2 \alpha}[21]$ or synthetic analogues of $\mathrm{PGF}_{2 \alpha}$ (cloprostenol) [22] is effective in causing luteolysis in heifers or cows except for 4 or 5 days after estrus [23]. During anoestrus, fluorogestone acetate (FGA) intravaginal sponges for 11 days in conjuction with PMSG (Pregnant Mare Serum Gonadotrophin) (750 IU) and cloprostenol (50 $\mu \mathrm{g}) 48$ hours before sponge removal resulted in $87.5 \%$ and $93.8 \%$ estrus response and fertility, respectively in Alpine does [24]. Two intramuscular injections of cloprostenol $(125 \mu \mathrm{g})$ administered 10 days apart in Mehsana does were as effective as the progestagen treatments tested [25].
The deficiency in myometrial contractility after breeding is responsible for the delay in uterine clearance and may also account for the retention of placenta, endometritis and pyometra which is responsible for the absence of cyclic activity in domestic animals. The incidence of endometritis is highest during the first 14 days post-partum. Progesterone makes the uterus more prone to uterine infection [26], which increases the chance to develop the condition like endometritis and pyometra. Retained placenta is also one of the main risk factor for the acute post-partum endometritis, pyometra and delay uterine involution. Cows with retained placenta have been shown to contain relatively higher level of progesterone and lower $\mathrm{PGF}_{2 \alpha}$ in their placentomes [27]. Musah et al. [28] suggested that relaxin combined with cloprostenol reduces the incidence of retained placenta in heifers. Now a day cloprostenol is drug of choice for the uterine cleanser in retention of placenta, endometritis and pyometra.

Abortion induction can be necessary in some cases, such as incompletion of maternal growth at the first gestation in heifers because of higher risk for dystocia and retention of placenta. Moreover, termination of gestation is necessary for eliminating low producing cows from herds and in cases of stillbirth and pathological developments including maceration and mummification of foetus, hydroamnion and hydoallantios during prenatal life. $\mathrm{PGF}_{2 \alpha}$ and its analogues are used to terminate gestation. Mechanism by which $\mathrm{PGF}_{2 \alpha}$ induces abortion includes depressing peripheral progesterone level through leuteolysis and stimulating abdominal contraction and partial cervical relaxation [29]. Prostaglandin $\mathrm{F}_{2 \alpha}$ and its analogues have been shown to be reliable abortifacients when administered in the first 150 days of pregnancy [30] and were effective in the induction of parturition after 255 days of gestation [31]. Cloprostenol and other $\mathrm{PGF}_{2 \alpha}$ analogues will cause leuteolysis in nonpregnant sheep and by similar mechanisms should cause absorption or abortion of embryos in sheep during early pregnancy (up to 55 days) [32]. Cloprostenol (an analogue of prostaglandin $\mathrm{F}_{2 \alpha}$ ) and dexamethasone in combination would induce abortion in feedlot heifers, regardless of the stage of gestation [33].

\section{Use to enhance Breeding Efficiency}

Breeding efficiency is one of the key factors for the determination of economic success of a cow-calf operation. In general, to obtain maximum economic benefit cattle should calve once per year. It is a critical 
component of a successful dairy operation, whereas reproductive inefficiency is one of the most costly problems facing the dairy industry today. Reproductive disorders occur frequently in lactating dairy cows and can dramatically affect reproductive efficiency in a dairy herd. Some of the most common disorders include ovarian cysts, twinning, early embryonic loss and retained placenta. These are diverse disorders that are similar in that they all can result in impaired reproductive function. Twinning is an unavoidable outcome of reproduction in dairy cattle and is undesirable in a dairy operation because it reduces overall profitability and reproductive efficiency [34]. To improve reproductive efficiency, it is necessary to inseminate cows early in the breeding season so that repeat inseminations can be performed early, thereby achieving a more compact calving season. Breeding efficiency is increased by means of synchronization of estrus, conception rate and pregnancy rate. Estrous synchronization together with Artificial Insemination in ewes is important in the improvement of reproductive efficiencies and management processes.

Estrus synchronization means to bring a group of animals in a same stage of estrus cycle so that they may come into estrus and ovulate at the same time. It is good managemental tool for programmed breeding, hence leading to programmed feeding and easier management of the cows being at the same stage of gestation. Finally, the calving will also be easy and convenient due to expected date of calving spread over a shortest possible period. Estrus synchronization can be achieved by lysis of corpus luteum by administration of Prostaglandin $\left(\mathrm{PGF}_{2 \alpha}\right)$ or its synthetic analogue on 5-17 days of the estrus cycle. The cows will return to estrus within 3-5 days [35]. Most estrus synchronization programs in dairy cattle mainly involve the use of the luteolytic agents prostaglandin or its analogues. Prostaglandin is only effective in diestrus cows; a double prostaglandin protocol applied 11-14 days apart seems to be capable of bringing most cows to estrus [36]. The double-injection regimen of Cloprostenol was highly effective in synchronizing estrus in heifers and the time of onset of estrus was similar to that reported by Cooper [10].

Estrus synchronization in Sudanese Nubian does was achieved with double dose of cloprostenol (125 $\mu \mathrm{g})$ together with intravaginal sponges impregnated with progesterone inserted for 16 days [37]. During the breeding season, when goats are actively cycling, estrus can be synchronized with $\mathrm{PGF}_{2 \alpha}$ or one of its analogues, such as cloprostenol [38]. PGF $_{2 \alpha}$ (dinoprost tromethamine, $5 \mathrm{mg}$ or $10 \mathrm{mg}$ ) or its analogue cloprostenol $(62.5 \mu \mathrm{g}, 125 \mu \mathrm{g}$ or $250 \mu \mathrm{g})$ can be used for synchronization of estrus in cyclic does. A double injection regimen with an interval of 10 to 14 days between injections is usually used. Two injections of cloprostenol at the rate of $62.5 \mu \mathrm{g}, 125.0 \mu \mathrm{g}$ and 250.0 $\mu \mathrm{g}$ administered 14 days apart, were effective in synchronizing doe during breeding season [39]. The response rate approaches 90 to $100 \%$ with conception rates varying from 65 to $75 \%$. Onset of estrus is usually expected 55 to 65 hours after treatment [40]. Approximately $80 \%$ of the gilts inseminated at a $\mathrm{PGF}_{2 \alpha}$ synchronized estrus had embryos 4-7 days or 24-30 days later [41].

Estrus synchronization schedule in mares involves the administration of $\mathrm{PGF}_{2 \alpha}$ or one of its analogues and gonadotropic hormones [42]. In randomly cycling mares, this method occur variations of results in a reasonably well synchronized onset of estrus and occurrence of ovulation. Conception rates in mares following such treatment have been variably reported as $39.9 \%$ [43], 40\% [42], 58\% [44] and 68\% [45]. Synchronization of ovulation using prostaglandins or its analogues (cloprostenol) requires the presence of active corpora lutea and thus a previous knowledge of the seasonal ovulatory activity of ibex females in December-January [46].

Cloprostenol have been used widely for the controlled induction of farrowing. The advantages are to improve batch farrowing and to induce farrowing in the daytime (24-36 hours after injection), when labour is more readily available and farrowing can be better supervised. This enables prompt assistance to be given to a sow, which may have difficulty and ensures safer delivery of the piglets and reduces stillbirths. It also facilitates colostrum management, with supervisors ensuring piglets start to suckle. Cloprostenol act on the corpora lutea of pregnancy in the sow's ovaries and cause them to regress, signaling to the body that it is time to give birth. The injection is normally given within two days of the individual farm's calculated average farrowing date (approximately 115 days but range 111-119 days) to avoid problems with weak piglets, which may affect viability. The majority of treated sows had farrowed by 35 hours after treatment [47].

Armstrong et al. [48] also observed significant increase in first service conception rate in cows receiving $\mathrm{PGF}_{2 \alpha}$ treatment during early postpartum and similar were the observations of Shah [49] in buffaloes. Moment and Seguin [50] showed a high conception rate $(73 \%)$ in heifers treated with $\mathrm{PGF}_{2 \alpha}$ 
analogue on $7^{\text {th }}$ day of the estrous cycle and only $21 \%$ in heifers treated on $10^{\text {th }}$ day conceived after a single fixed- time Artificial Insemination. Kristula and Bartholomew [51] reported that $\mathrm{PGF}_{2 \alpha}$ analogues avoid retensio-secundinarium during the postpartum period and achieve a $20 \%$ higher pregnancy rate. Pursley et al. [52] reported a higher pregnancy rate in the $\mathrm{PGF}_{2 \alpha}$ and GnRH cows were treated with intramuscular.

\section{Conclusions}

Cloprostenol alone or in combination with different hormones has proved to be efficient in treating anoestrous, synchronizing estrus in postpartum dairy cows, improving reproductive efficiency in dairy farms. It has been proved to administer $\mathrm{PGF}_{2 \alpha}$ or its analogue in early postpartum cows and buffaloes in order to hasten early resumption of cyclic ovarian activity and thereby to increase the reproductive efficiency. For the purpose of treatment of anoestrus and to improve breeding efficiency Cloprostenol is one of the most effective drug.

\section{References}

1. Opsomer, G., Mijtem, P., Coryn, M. and Kruif, A. D. (1996). Postpartum anoestrus in dairy cows: A review. Veterinary Quarterly. 18 (2): 68-75.

2. Sirohi, N. S., Monga, D. P. and Knar, S. K. (1989). Microbiological studies on some reproductive disorders of cattle. Indian Journal of Animal Sciences. 59(5): 537-541.

3. Singh, N. P., Chaturvedi, V. K. and Singh, D. P. (1996). Bacteriological studies on repeat breeder bovines. Indian Veterinary Journal. 73 (4): 462-463.

4. Dholakia, P. M., Shah, N. M., Purohit, J. H. and Kher, H. N. (1987). Bacteriological study on non-specific genital infection and its antibiotic spectra in repeat breeders. Indian Veterinary Journal. 64 (8): 637-640.

5. Elliott, L., McMahon, K. J., Gler, H. T. and Marion, G. B. (1968). Uterus of the cow after parturition: Bacterial content. American Journal of Veterinary Research 29: 77.

6. Rahman, A., Rahman, A., Rahman, H. and Ahmed, M. U. (1996). Anoestrus and repeat breeding problems in indigenous cattle in Bangladesh. Tropical Animal Health Production. 7: 605-609.

7. Arthur, G. H., Noakes, D. E. and Pearson, H. (1989). Veterinary Reproduction and Obstetrics. 6th ed. Baillie're Tindall, Philadelphia, PA.

8. Tenhagen, B. A. and Heuweisier, W. (1999). Comparison of a conventional reproductive management programme based on rectal palpation and uterine treatment of endometritis with a strategic $\mathrm{PGF}_{2 \alpha}$ programme. Zentralbl Veterinarimed A. 46 (3): 167-76.
9. Rigby, S. L., Barhoumi, R. and Burghardt, R. C. (2001). Mares with delayed uterine clearance have an intrinsic defect in myometrial function. Biol. Reprod. 65: 740-747.

10. Guler, M. D. A., Dinc, A., Semacan, M., Aksoy, K., Isik and Erdem, H. (1993). The luteolytic effect and pregnancy rate of Luprostiol administered via different routes and various doses in heifers (In Turkish). J. Fac. Vet. Med. Univ. Selcuk. 9(2): 69-73.

11. Weems, C. W., Weems, Y. S. and Randel, R. D. (2006). Prostaglandins and reproduction in female farm animals. The Veterinary Journal. 171: 206-228.

12. Serrero, G. and Lepak, N. M. (1997). Prostaglandin $\mathrm{F}_{2 \alpha}$ receptor (FP receptor) agonists are potent adipose differentiation inhibitors for primary culture of adipocyte precursors in defined medium. Biochem. Biophys. Res. Commun. 233: 200-202.

13. Poyser, N. L. (1992). Prostaglandins in animal reproduction. Agricultural Biotechnology News and Information. 4: 17-25.

14. Fisch, B., Rose, M. P., Elder, M. G., Winston, R. M., Margara, R. A. and Hillier, S. G. (1994). Effects of oestrogen and progesterone synthesis and arachidonic acid metabolism in human luteal cells. Clinical Endocrinology. 40: 21-32.

15. Auletta, F. J. and Kelm, L. B. (1994). Mechanisms controlling corpus luteum function in the rhesus monkey (Macaca mulatta): Inhibitory action of hCG on luteolysis induced by $\mathrm{PGF}_{2 \alpha}$. Journal of Reproduction and Fertility. 102: 215-220.

16. Auletta, F. J., Kelm, L. B. and Schofield, M. J. (1995). Responsiveness of the corpus luteum of the rhesus monkey (Macaca mulatta) to gonadotrophin in vitro during spontaneous and prostaglandin $\mathrm{F}_{2 \alpha}$ - induced luteolysis. Journal of Reproduction and Fertility. 103: 107-113.

17. Colak, A., Oral, H., Pancarci, S. M. and Hayirli, A. (2008). Comparison of the efficacy of the administration route of d-cloprostenol to induce abortion in undesirable pregnancy. Journal of Animal and Veterinary Advances. 7 (8): 903-906.

18. Fieni, F. (2006). Clinical evaluation of the use of aglepristone, with or without cloprostenol, to treat cystic endometrial hyperplasia-pyometra complex in bitches. Theriogenology. 66: 1550-1556.

19. Tsai, S. J., Kot, K., Ginther, O. J. and Wiltbank, M. C. (2001). Temporal gene expression in bovine corpora lutea after treatment with prostaglandin $\mathrm{F}_{2 \alpha}$ based on serial biopsies in vivo. Reproduction. 121:905-913.

20. Shah, R. G., Kharadi, V. B., Dhami, A. J., Desai, P. M. and Kavani, F. S. (2002). Effect of gonadotrophin releasing hormone on reproductive performance and steroid profile of postpartum suckled Surti buffaloes. Indian J. Anim. Sci. 72: 1076-1082.

21. Roche, J.F. (1974). Synchronization of estrus and fertility following artificial insemination in heifers given prostaglandin $\mathrm{F}_{2 \alpha}$.J. Reprod. Fert. 37: 135-138.

22. Cooper, M. I. (1974) Control of estrous cycles of 
heifers with a synthetic prostaglandin analogue. Vet. Ree. 95: 200-203.

23. Louis, T. M., Hafs, H. D. and Seguin, B. E. (1973). Progesterone, LH, estrus and ovulation after prostaglandin $\mathrm{F}_{2 \alpha}$ in heifers. Proc. Soc. exp. Biol. Med. 143: 152-155.

24. Freitas, V. J., Baril, G. and Saumande, J. (1996). Induction and synchronization of estrus on goats: The relative efficacy of one versus two fluorogestone acetate impregnated vaginal sponges. Theriogenology. 46: $1251-1256$

25. Kusian, N. T., Tarwinei, F., Hamudikuwanda, H., Agumba, G. and Mukwena, J. (2000). A comparison of effect of progesterone sponges and ear implant, $\mathrm{PGF}_{2 \alpha}$ and their combination of efficiency of estrus synchronization and fertility of Mehsana does. Theriogenology. 53: 1567-1580.

26. Hendricks, K. E. M., Bartolome, J. A., Melendez, P., Risco, C. and Archbald, L. F. (2006). Effect of repeated administration of $\mathrm{PGF}_{2 \alpha}$ in the early post partum period on the prevalence of clinical endometritis and probability of pregnancy at first insemination in lactating dairy cows. Theriogenology. 65: 1454-1464

27. Leidl, W., Hegner, P. and Rockel, P. (1980). Investigations on the $\mathrm{PGF}_{2 \alpha}$ concentration in maternal and foetal cotyledons of the cows with and without retained foetal membranes. Zentralbl Veterinaerimed. 27: 77-95.

28. Musah, A. I., Schwabe, C. and Anderson, L. L. (1987). Acute decrease in progesterone and increase in estrogen secretion causes by relaxin during late pregnancy in beef heifer. Endocrinology. 120: 317 324 .

29. Thomas, P. G. A. (1997). Induced abortion. In: Youngquist R. S. (Ed.). Current Therapy in Large Animal Theriogenology, W. B. Saunders Company, London, pp: 898.

30. Copeland, D. D., Canady, J. D., Kelly, J., Schultz, R. H. and Godke, R. A. (1979). Inducing abortion in feedlot heifers during mid-gestation with cloprostenol (ICI-80,996). J. Anim. Sci. 49(1): 287.

31. Henricks, D. M., Rawlings, N. C., El-Licott, A. R., Dickey, J. F. and Hill, J. R. (1977). Use of prostaglandin $\mathrm{F}_{2 \alpha}$ to induce parturition in beef heifers. J. Anim. Sci. 44: 438-441.

32. Acritopoulou, S., Haresign, W., Foster, J. P. and Lamming, G. E. (1977). Plasma progesterone and LH concentrations in $\mathrm{PGF}_{2 \alpha}$ J. Reprod. Fertil. 49: 337340 .

33. Barth, A. D., Adams, W. M., Manns, J. G., Kennedy, K. D., Sydenham, R. G. and Mapletoft, R. J. (1981). Induction of abortion in feedlot heifers with a combination of cloprostenol and dexamethasone. Can. Vet. J. 22: 62-64.

34. Beerepoot, G. M. M., Dykhuizen, A. A., Mielen, M. and Schukken, Y. H. (1992). The economics of naturally occurring twinning in dairy cattle. J. Dairy
Sci. 75:1044-1051.

35. Salisbury, G. W., VanDemark, N. L. and Lodge, J. R. (1978). Physiology of Reproduction and Artificial Insemination of Cattle, 2nd edition. W.H. Freeman and Company, New York.

36. Diaz, C. A. G., Ebru Emsen, N., Tuzemen, M., Yanar, M., Kutluca, M. and Koycegiz F. (2005). Reproductive performance and synchronization of estrus in Brown swiss and Holstein cows and heifers using $\mathrm{PGF}_{2 \alpha}$. Journal of Animal and Veterinary Advances. 4(5): 551-553.

37. Muna, M., Ahmed, M., Malawi, S. E. and Jubara, A. S (1998). Synchronization of estrus in Nubian goats Small Rum. Res. 30: 113-120.

38. Gordon, I. (1997). Controlled reproduction in Sheep and Goats. $1^{\text {st }}$ Edn., Vol. 2., CAB International, Walingford, UK. PP: 351- 439.

39. Grayling, J. P. C. and Van Niekerk, C. H. (1986) Synchronization of estrus in the Boer doe: Dose effect of prostaglandin in the double injection regimen. South Afr. Sci. 16: 146- 150 .

40. Lopez-Sebastian, A., Gonzalez-Bulnes, A. and Carrizosa, J. A. (2007). New estrus synchronization and artificial insemination protocol for goats based on male exposure, progesterone and cloprostenol during the non-breeding season. Theriogenology. 68: 1081-1087.

41. Guthrie, H. D. and Polge, C. (1976b). Control of estrus and fertility in gilts with accessory corpora lutea by prostaglandin analogues, ICI 79,939 and ICI 80,996. J. Reprod. Fert. 48: 427-430.

42. Martin, J. C., Klug, E., Merkt, H., Himmler, V. and Jochle, w. (1981). Luteolysis and cycle synchronization with a prostaglandin analogue for artificial insemination in the mare. Theriogenology. 16: 433-446.

43. Voss, J. L., Wallace, R. A., Squires, E. L., Pickett, B. W. and Shideler, R. K. (1979). Effects of synchronization and frequency of insemination on fertility. J. Reprod. Fertil. (Suppl). 27: 257-261.

44. Palmer, E. and Jousset, B. (1975). Synchronization of estrus in mares with a prostaglandin analogue and hCG. J. Reprod. Fertil. (Suppl). 23: 269-274.

45. Hyland, J. H. and Bristol, F. (1979). Synchronization of estrus and timed insemination of mares. J. Reprod. Fertil. (Suppl). 27: 251-255.

46. Santiago-Moreno, J., Gómez-Brunet, A., GonzálezBulnes, A., Malpaux, B., Chemineau, P., Pulido, A. and López-Sebastián, A. (2003). Seasonal ovulatory activity and plasma prolactin concentrations in Spanish ibex (Capra pyrenaica hispanica) maintained in captivity. Reprod. Nutr. Dev. 43: $217-$ 224.

47. Cameron, R. D. A., Kieran, P. J. and Martin, I. (2000). The efficacy in inducing batch farrowing and the impact on sow behaviour of the prostaglandins cloprostenol and dinoprost. Proceedings of the 16th International Pig Veterinary Society Congress, 
Melbourne, Australia, p 386.

48. Armstrong, J. D., O'Gorman, J. and Roche, J. F. (1989). Effects of prostaglandin on the reproductive performance of dairy cows. Vet. Rec. 125: 597-600.

49. Shah, R. G. (1999). Hormonal and biochemical profile in fertile and infertile postpartum Surti buffaloes. Ph. D. Thesis, Gujarat Agricultural University, Anand Indian.

50. Moment, H. W., and Seguin, B. E. (1984). Influence of day of estrus cycle on response to $\mathrm{PGF}_{2 \alpha}$ products:
Implication for AI programs for dairy cattle. Proc. 10 $0^{\text {th }}$ Int. Congr. Anim. Reprod. and A. I. 3: 336

51. Kristula, M. A. and Bartholomew, R. (1998). Evalution of prostaglandin $\mathrm{F}_{2 \alpha}$ treatment in dairy cows at risk for low fertility after parturition. Journal of the American Veterinary Medical Association. 212(5): 702-704.

52. Pursley, J. R., Mee, M. O. and Wiltbank, M. C. (1995). Synchronization of ovulation in dairy cows using $\mathrm{PGF}_{2 \alpha}$ and GnRH. Theriogenology. 44(7): 915-923. 